\title{
Collaborative Governance to Increase Building Index in Economics Through Village-Owned Enterprises Sub- District Ngroto, Malang
}

\author{
Laeli Nur Khanifah ${ }^{1 *}$, Iradhat Taqwa Sihidi ${ }^{1}$, Krishno Hadi ${ }^{1}$ \\ ${ }^{1}$ Department of Governmental Sciences, Universitas Muhammadiyah Malang, Malang, Indonesia \\ "Corresponding author. Email: khanifah92@umm.ac.id
}

\begin{abstract}
Law 6 of 2014 cites Village-Owned Enterprises as Business Entities, whose capital is owned by the Village and is obtained from Village assets to facilitate the welfare of the Village community. The government must understand the potential in its territory and manage it together with the community, the private sector, and the Village Government for its sustainability. The success of Ngroto Village in establishing and running VillageOwned Enterprises Ageng made Ngroto one of the independent villages with IDM 94. Further research is to answer how the collaboration patterns between the government and various stakeholders in achieving economic empowerment in Ngroto Village. This research method uses descriptive qualitative and data collection interviews, observations, and documentation. The results of the study indicate the success of the government in achieving an increase in IDM over the past four years because it encourages public confidence in local government. In the economic field, cooperation to realize by the role of Ageng Village-Owned Enterprises, which has three units, namely savings and loans, partners, and users of drinking water. Savings and loan units with low interest and coupled with training/business assistance have been proven to contribute to reducing the number of poor people from 477 in 2015 to 297 in 2018. The above facts prove that collaborative collaboration is strengthened and proven to support development in villages and needs to be a model for development models in rural areas in Indonesia.
\end{abstract}

Keywords: collaborative governance, independent village, village-owned enterprises

\section{INTRODUCTION}

Before getting the title as a village with the status as the highest index building village, in 2014, Ngroto village located in the Pujon sub-district, Malang district, was only a developing village with a village index value building 0.64 or 64. However, four years later, Ngroto Village won the best national village ranking in 2018 by getting the highest score in the Building Village Index of 94. This assessment is based on indicators in the index of developing villages, namely health, education, settlement, social capital, economic security, environmental quality, and potential for disaster-prone. It should be noted that the Village Build Index, was developed to strengthen efforts to achieve the village and Rural Area development targets as stated in the 2015-2019 National Medium-Term Development Plan Book [1], which is to reduce the number of Disadvantaged Villages to 5000 Villages and increase the number of Independent Villages to at least 2000 Villages in 2019 Developing Villages classifies Villages in five statuses, namely: 1) Very Underdeveloped Village with a value $<0.491$; 2) Underdeveloped Villages: $>0.491$ and $<0.599$; 3 ) Developing Villages: $>0.599$ and $<0.707$; 4) Advanced Villages: $>0.707$ and $<0.815$ and 5) Independent Villages:> 0.815 .

The success of Ngroto Village in achieving the highest Village Building Index, including in the field of economic resilience is carried out through the establishment of an economic institution that is fully managed by the village community, namely the Village Owned Enterprise as one of the mainstay programs in increasing the independence of the village economy. Village-Owned Enterprises are managed with a family spirit and cooperation which is explained in article 87 of the Village Law, and the results of the efforts of Village-Owned Enterprises are utilized for business development and village development, empowering village communities, and providing assistance to the poor through grants, social assistance, and revolving fund activities stipulated in the Village Revenue and Expenditure Budget [2] If seen from its function, VillageOwned Enterprises are actually one of the driving pillars in economic activities in the village that function as commercial institutions and social institutions. VillageOwned Enterprises as a commercial institution, of course, aims to gain profit through offering local resources that are both goods and services to the market, while VillageOwned Enterprises as social institutions, of course, must side with the common interest, namely prioritizing the interests of the community through its contribution in providing social services [3].

Several studies have been conducted related to VillageOwned Enterprises, including research by [4], [5], [6], which explains examples of the success of Village-Owned Enterprises in developing the village economy and VillageOwned Enterprises as a village-scale local authority that has been implemented by the Village. In addition to success, 
research conducted by [7]. Discusses the failure or noncontinuity of the Village-Owned Enterprises that have been formed but have stopped traveling.

The success of Village-Owned Enterprises is not only a matter of formation, but the long-term benefits and resilience mean that Village-Owned Enterprises can contribute to villages and village communities, rather than being talkative in forming Village-Owned Enterprises without seeing the potential that exists in the village. Besides, control from the community to participate in planning the formation and management and evaluation of Village-Owned Enterprises is needed to avoid temporal interests.

The success of the implementation of the "Village Building" program by Ngroto Village through the Village Enterprises Agency is undoubtedly very much determined by cooperation and careful planning that is able to answer problems and anticipate opportunities and challenges that arise carefully, and in the process carried out in a participatory manner involving all stakeholders including the community and village apparatus / apparatus. Excellent and well-planned village program management will result in proper program implementation, and in turn, will foster community participation to be involved in village development.

Collaborative Governance in the formation of villageowned enterprises by Ngroto Village is based on the aim of solving problems together from bound parties. These parties are not only limited to government and non-government institutions because in the principles of good governance, but civil society is also involved in the formulation and decision making [8].

Cooperation or Collaborative Governments here are governments arranged by involving public bodies and nongovernmental organizations in the process of formalizing decisions, formally oriented towards consensus, and there is a division of tasks in carrying out public policies or managing public programs, and public assets [9]. Hence, this research investigates the collaborative Governance in sub-district Ngroto to building index through Villageowned enterprises.

\section{RESEARCH METHODS}

This research uses descriptive qualitative methods. Such a research model examines objectively and naturally on a phenomenon [10]. The qualitative approach is considered representative to analyse and understand the phenomenon of Collaborative Governance to increase the Village Build Index in Economy through in Malang. Data were collected through depth interview with the head of Village-Owned Enterprises and Headman of Ngroto. Documentation was obtained from photographs of the activities of VillageOwned Enterprises and the public, whereas other data sources also come from books, journals, and news. Data analysis methods used are reduction, display, and data interpretation.

\section{RESULTS AND DISCUSSION}

\subsection{Collaborative Governance in Increasing the Village Building Index}

The Village Build Index is a Composite Index formed from the Social Resilience Index, the Economic Resilience Index, and the Village Ecological Resilience Index. In this study, the researchers only focused on the economic resilience index. Ngroto Village is the best national village in poverty alleviation. This success is inseparable from the collaboration of district and village governments to be one of the keys to the success achieved by Desa Ngroto. Besides that, synchronizing various poverty alleviation policies such as Jalin Matra and the Rural Poverty Reduction Movement Program (GalangKesan) became the trigger for the success of poverty alleviation in Ngroto Village.

Poverty alleviation activities in Ngroto Village began when Malang Regency Bappeda established the vegetableproducing Village to be a pilot for poverty alleviation projects. The initial step taken by the village government is to initiate to build cooperation with all stakeholders starting from the Village apparatus, Non-Governmental Organizations, and universities. This collaboration is intended to map the number of poor people, along with the problems faced by them, so that it can be programmed in activities that will be made directly to overcome the root problems.

Based on the initial conditions of mapping the problems carried out by the government and poor household groups, the socio-cultural and economic environment also triggered a large number of Ngroto villagers who were entangled in loan sharks in the form of mobile banks, needs and offered that were continuously given from their homes by the Mobile Bank people are tempted to use a mobile bank as a leading source of capital in developing their business even with high interest. Of course, these conditions make it difficult for the community to develop and even fall into more misery.

With the map of the problem above and the design of the activities, an agreement was reached on the need to strengthen the people's economic institutions, so Villageowned enterprises Ngroto was formed, which would later play a role in strengthening the village economy by channelling various assistance to the community.

\subsection{Building an Economy Through Village- Owned Enterprises}

The village-owned business entity is mandated by Law No. 6 of 201411 concerning Villages as one of the efforts of the Village to improve the economy of the village community, especially businesses in the village that aim to seek profits which will be used as much as possible for the benefit of the village and the community [11].

There are at least two reasons put forward by Ngroto Village stakeholders regarding the importance of Village-owned Enterprises for the Village community. First, village-owned businesses have a role as a driver of the economy through 
various economic potential development activities. While the second, the implications of the above economic development can open jobs so that it is hoped that rural communities do not need to go outside the city to work. However, the establishment of Village-owned enterprises does not intend to shut down existing community economic enterprises but rather support existing businesses.

Ageng village-owned business entity is a business entity in Ngroto village to drive the economy of the village community. The name "AGENG" was chosen as a result of deliberations involving the community and community leaders with the random reason, because Ageng was the name of the first person in Ngroto Village, namely Ageng Ronggo Pramono. "AGENG" is also an abbreviation of ANGGAYUH EKONOMINE NGROTO. Which in Indonesian is interpreted as a prayer to achieve a more prosperous Ngroto Village economy.

With the vision of "Towards an Independent and Prosperous Ngroto Village Economy", the establishment of Ageng Village-Owned Enterprises was approved in the decree of the village head No. 412.31 / 30 / 35.07.26.2006 / 2015 concerning administrators of Village-Owned Enterprises by carrying out missions 1) exploring and exploiting economic potential Village 2) increasing small and medium businesses to increase employment opportunities 3) providing easy and inexpensive capital for the community 4) increasing the competitiveness of the community's economic activities 5) developing economic business units in all fields 6) realizing superior products to strengthen the village economy in accordance with the Characteristics Village and 7) realizing the prosperous and self-reliant Ngroto Village community.

The business units managed by village-owned enterprises include several Business Units; First Savings and Loans Unit, Savings and Loans Unit Matra is a form of poverty management, which is the initiation of the East Java provincial government. The Matra Jalin Savings and Loan budget come from special financial assistance from the provincial government. This program focuses on the community of small and medium businesses - especially those who are on the list of almost poor households. To provide access to capital to the community of small business operators who are not registered in the Target Household or Nearly Poor Household survey results of the 2011 PPLS, then they can make a PUK loan carried out with the same scheme as the Loan Matra Loan. However, the difference is the loan interest, which is $1 \%$.

Second, Seed Business Loans, the potential of rural communities as captors in breeding horticultural agricultural seeds, is often constrained by agricultural seed capital. Many of the farmers who have difficulty in seed capital are borrowing through individuals with significant interest rates returning so often the yields obtained are not following the results that should be due to be cut to return the seeds. Thus, for the development of community economic activities, especially agricultural nurseries, the seed business is carried out with a savings scheme. The program is aimed at fostering lifestyles that are frugal and are diligent in saving.

For this reason, Ageng village-owned enterprise also runs a savings unit, which is divided into five types of savings. First, general savings is intended for anyone who wants to save money. And it is recommended for residents who have loans at village-owned enterprises such as Matra. This savings interest rate is $4 \%$ per year with an initial deposit of IDR 50,000, and the next deposit is a minimum of IDR 5,000 . If the withdrawal transaction is above IDR 200,000, it will be deducted with a withdrawal of IDR 2000. Second, Savings for School Children, Due to the conditions in the village of Ngroto, which has many educational institutions ranging from elementary schools to high schools totaling 17 institutions. Thus, there is a need for a savings program for school children. Third, Tabungan Hari Raya, which is a holiday celebrated by many residents of Ngroto village, of course, requires a substantial cost, thus this savings aims to prepare for the needs of the community when approaching the holiday with an interest of 5\% per year and this savings can only be disbursed when approaching Ramadan or before the holiday. Fourth, the savings program for basic food needs is savings with a value following the items ordered and paid for every week for 40 weeks. With the agreement, if the price of goods at the time of search is higher than the initial agreed upon, customer customers add a price difference.

On the contrary, if the price is lower, then the village-owned business will return the value using the price difference. Fifth, Deposits are carried out to accommodate community deposits for an extended period. They can only be disbursed with a specific period that is three months, six months, or one year with a deposit service of $6 \%$ per year.

Third, the agricultural shop unit is following the potential of the ngroto village resources, which are more likely to be agricultural, so meeting the needs for agricultural facilities such as seeds, fertilizers, medicines is a basic need in developing the people's economy. Thus since September 2016, this unit was held for business in meeting the needs of farmers in Ngroto Village through the Ageng Village Farm Shop. Lastly, Business Creativity aimed at increasing business activities and increasing the income of Ageng village-owned enterprises by carrying out creative activities, among others, first, BNI 46 Agents, the activities of cooperation with BNI include bookkeeping, savings accounts and savings deposits, e-payment Payment for electricity, PDAM, cellphone credit, ticket, etc. Secondly, this activity BULOG collaborates with Bulog Sub Drive through the procurement of cheap food for the community such as oil, sugar, salt, rice, flour, onions, etc. Third, Ageng Motor Washing Business activity is carried out by the youth of Ngroto Village as a new job field. The Fourth Drinking Water Business. This business unit is a form of meeting drinking water needs because the availability through PDAM is minimal. The provision of drinking water is made by drilling underground water to meet drinking water needs, especially in the Krajan Hamlet area, which often experiences drinking water shortages.

Role Ngroto village-owned enterprises at least have an essential role in assisting in accessing small businesses to existing financial sources or financial institutions. The success of Ngroto Village in alleviating poverty, according to Prayogi (Head of Village Ngroto), is acknowledged to be supported by the existence of the Ngroto village-owned business entity in managing community capital businesses. The implication is that low-income families experience a significant decline. Recorded in the Ngroto Village Profile 
[2] T. V. Yustisia, Undang-Undang Nomor 6 Tahun 2014 Tentang Desa dan Peraturan Terkait: VisiMedia, 2015 .

[3] M. Yasin, T. Ketema, and K. Bacha, "Physicochemical and bacteriolossssgical quality of drinking water of different sources, Jimma zone, Southwest Ethiopia," BMC research notes, vol. 8, p. 541, 2015.

The success of Collaborative Governance carried out by the Ngroto Village government in the economic field as an independent village is inseparable from the participation of the village government, Ageng village-owned enterprises, and community participation. In the economic field, cooperation is realized by the role of Ageng Village-Owned Enterprises that have six units, namely savings and loans, seed business loans, savings, agricultural shop units, and business creativity. Savings and loan units with low-interest rates coupled with business training/assistance have been proven to contribute to reducing the number of poor people from 477 in 2015 to 297 in 2018 . The facts above prove that collaborative collaboration is strengthened and proven to support development in the village and needs to be a model for development models in rural areas in Indonesia.

\section{ACKNOWLEDGMENTS}

The author would like to thank the Faculty of Social and Political Sciences, the University of Muhammadiyah Malang, as funding of this research. I also say to thank you for the management of the Village-Owned Enterprises and Village Office Ngroto, Malang, who provided relevant data and information for this research.

\section{REFERENCES}

[1] B. P. P. Nasional, "Rencana Pembangunan jangka menengah nasional (RPJMN) 2015-2019," Peraturan Presiden Republik Indonesia Nomor, vol. 2, 2014.
[4] R. A. Prasetyo, "Peranan BUMDES dalam Pejambon Kecamatan Sumberrejo Kabupaten 2016.

[5] A. H. Munawar, T. J. Hayat, and J. A. Nurhasan, "Efektivitas peran bumdes terhadap peningkatan pendapatan masyarakat di desa panjalu," ANTARADHIN, vol. 1, pp. 133-151, 2018.

[6] E. S. S. Ningrum and S. Hermawan, "Analisis Aspek Transparansi Dan Akuntabilitas Pengelolaan Apbdes Dan Kemungkinan Berdirinya Bumdes," Universitas Muhammadiyah Sidoarjo, 2018.

[7] D. Faedlulloh, "Bumdes dan kepemilikan warga: membangun skema organisasi partisipatoris," Journal of Governance, vol. 3, 2018.

[8] A. Rofieq, H. Husamah, S. Wahyuni, I. Hindun, and E. Purwanti, "Research Methodology through Writing Research Proposal Retrospectively by Combining Classroom Discussion and Collaborative Working Group in Lesson Study," in Proceeding of International Conference on Teacher Training and Education, 2016.

[9] C. Ansell and A. Gash, "Collaborative governance in theory and practice," Journal of public administration research and theory, vol. 18, pp. 543-571, 2008.

[10] A. Anggito and J. Setiawan, Metodologi penelitian kualitatif: CV Jejak (Jejak Publisher), 2018.

[11] R. Indonesia, "Undang-Undang No. 6 Tahun 2014 tentang Desa," Jakarta, Indonesia, 2014. Pembangunan dan Pemberdayaan Masyarakat di Desa Bojonegoro," Jurnal Dialektika, vol. 11, pp. 86-100, 